\title{
Praktik Higiene Sanitasi dalam Pengelolaan Pangan di Sepuluh Industri Jasa Boga di Kota Bogor
}

\section{(Hygiene and Sanitation Practices during Food Production in Ten Catering Industries in Bogor City)}

\author{
Widiati Purnawita ${ }^{1}$, Winiati Pudji Rahayu ${ }^{1,2 \star}$, Siti Nurjanah ${ }^{1,2}$ \\ (Diterima November 2019/Disetujui Mei 2020)
}

\begin{abstract}
ABSTRAK
Industri jasa boga merupakan suatu usaha pengelolaan pangan yang menghasilkan pangan siap saji atau pangan yang siap dikonsumsi langsung oleh konsumen tanpa pemasakan atau pemanasan terlebih dahulu. Oleh karena itu, keamanan pangan asal industri jasa boga menjadi sangat penting. Selama periode 2015-2017, pangan asal industri jasa boga menjadi penyebab terbesar ketiga insiden keracunan pangan di Indonesia. Hal tersebut menunjukkan rendahnya pemenuhan higiene sanitasi pangan di industri jasa boga, terutama dalam pengelolaan pangan. Penelitian ini bertujuan untuk mengukur tingkat pemenuhan prinsip higiene sanitasi dalam pengelolaan pangan di industri jasa boga. Penelitian dilakukan di 10 industri jasa boga yang berlokasi di Kota Bogor, yang terdiri atas 2 industri jasa boga golongan A2, 4 industri jasa boga golongan A3, dan 4 industri jasa boga golongan B. Pengumpulan data dilakukan dengan teknik observasi menggunakan checklist yang dikembangkan dari Peraturan Menteri Kesehatan Nomor 1096 Tahun 2011. Hasil menunjukkan bahwa tingkat pemenuhan prinsip higiene sanitasi dalam pengelolaan pangan di industri jasa boga golongan A2, A3, dan B termasuk ke dalam kategori cukup. Tahap penyimpanan bahan pangan di industri jasa boga golongan A2 dan tahap pengolahan pangan di industri jasa boga A2, A3, dan B memiliki tingkat pemenuhan prinsip higiene sanitasi yang masih kurang sehingga perlu lebih ditingkatkan.
\end{abstract}

Kata kunci: higiene sanitasi, industri jasa boga, tingkat pemenuhan, pengelolaan pangan

\section{ABSTRACT}

Catering industry is a food business which produces ready-to-eat food or food that will not be cooked or reheated before serving. Therefore, the safety of food produced by catering industry becomes very important. During period of 2015-2017, the food produced by catering industry was the third largest cause of food borne outbreak in Indonesia. This showed poor compliance level of food hygiene and sanitation in the catering industry, especially during food production. This study was aimed to measure the compliance level of sanitation and hygiene practices during food production in catering industries. This study was carried out in 10 catering industries located in Bogor City, consisting of 2 catering industries in class A2, 4 catering industries in class A3, and 4 catering industries in class B. Data collection was carried out by observation using checklist which was developed from Regulation of The Minister of Health Number 1096 Year 2011. Result showed that catering industries in class A2, A3, and B had an average compliance level of hygiene and sanitation practices during food production. The stage of raw material procurement in class A2 and stage of food processing in class A2, A3, and B were still in poor compliance level of hygiene and sanitation practices that should be more improved.

Keywords: catering industries, compliance level, hygiene and sanitation, food production

\section{PENDAHULUAN}

Berdasarkan Peraturan Menteri Kesehatan Nomor 1096 Tahun 2011 (Permenkes 1096/2011), industri jasa boga didefinisikan sebagai usaha pengelolaan pangan yang disajikan di luar tempat usaha atas dasar pesanan, yang dilakukan oleh perseorangan atau badan usaha. Berdasarkan kriteria luas jangkauan yang dilayani, industri jasa boga tersebut dibedakan

1 Departemen IImu dan Teknologi Pangan, Fakultas Teknologi Pertanian, Institut Pertanian Bogor, Kampus IPB Darmaga, Bogor 16680

2 SEAFAST Center, Lembaga Penelitian dan Pengabdian kepada Masyarakat (LPPM), Kampus IPB Darmaga, Bogor 16680

*Penulis Korespondensi: E-mail: wini_a@hotmail.com menjadi tiga golongan, yaitu golongan $A(A 1, A 2$, dan A3) yang melayani kebutuhan masyarakat umum, golongan B yang melayani kebutuhan masyarakat dalam kondisi tertentu (misalnya asrama, pabrik, dan fasilitas pelayanan kesehatan), dan golongan $\mathrm{C}$ yang melayani kebutuhan masyarakat di dalam alat angkut umum internasional dan pesawat udara. Industri jasa boga golongan A1 masih menggunakan dapur rumah tangga dan dikelola oleh keluarga, industri jasa boga golongan A2 masih menggunakan dapur rumah tangga, namun telah mempekerjakan tenaga kerja, sedangkan industri jasa boga golongan A3 telah menggunakan dapur khusus dan memperkerjakan tenaga kerja.

Pengelolaan pangan merupakan rangkaian kegiatan yang meliputi penerimaan bahan pangan segar 
atau pangan terolah, pembuatan, pengubahan bentuk, pengemasan, pewadahan, pengangkutan, dan penyajian. Permenkes 1096/2011 menyaratkan industri jasa boga dalam melakukan pengelolaan pangan untuk memenuhi prinsip higiene sanitasi agar pangan siap saji yang dihasilkan aman. Higiene sanitasi adalah upaya untuk mengendalikan faktor-faktor terjadinya kontaminasi pada pangan, baik yang berasal dari bahan pangan, orang, tempat, dan peralatan, agar pangan tersebut aman. Dalam upaya menjamin keamanan pangan siap saji, Permenkes 1096/2011 juga menyaratkan industri jasa boga untuk memiliki Sertifikat Laik Higiene Sanitasi dari Dinas Kesehatan Kabupaten/Kota sebagai syarat untuk memperoleh izin usaha.

Berdasarkan Laporan Tahunan yang diterbitkan oleh Badan Pengawas Obat dan Makanan pada periode 2015-2017, diketahui bahwa pangan asal industri jasa boga menjadi penyebab insiden keracunan pangan terbesar ketiga setelah pangan asal rumah tangga dan pangan jajanan. Insiden keracunan pangan tersebut paling banyak disebabkan oleh bakteri patogen, baik yang terkonfirmasi maupun yang dicurigai, dengan rincian 65\% pada tahun 2016 (BPOM 2017), $58,49 \%$ pada tahun 2017 (BPOM 2018), dan 66\% pada tahun 2018 (BPOM 2019). Data lainnya menyebutkan bahwa $74,9 \%$ insiden keracunan pangan yang terjadi di Indonesia pada tahun 2000-2015 disebabkan oleh bakteri patogen (Arisanti et al. 2018). Bakteri patogen yang berkontribusi di antaranya adalah Escherichia coli, Bacillus cereus, Staphylococcus sp, Salmonella, Clostridium sp, Shigella, Streptococcus, Enterobacter $\mathrm{sp}$, Vibrio parahaemolyticus, dan Vibrio cholerae (Arisanti et al. 2018; Budiati et al. 2018; Harjanti et al. 2018). Hal tersebut menunjukkan rendahnya pemenuhan higiene sanitasi pangan di industri jasa boga, terutama dalam pengelolaan pangan.

Pemeriksaan higiene sanitasi pangan di industri jasa boga yang selama ini dilakukan Dinas Kesehatan Kabupaten/Kota lebih banyak memberikan fokus pada pemenuhan persyaratan teknis fisik, seperti bangunan, fasilitas, peralatan, dan tenaga kerja, serta persyaratan cemaran kimia dan biologi pada pangan, sedangkan pemeriksaan terkait pemenuhan prinsip higiene sanitasi dalam pengelolaan pangan masih sangat terbatas. Oleh karena itu, penelitian ini bertujuan untuk mengukur tingkat pemenuhan prinsip higiene sanitasi dalam pengelolaan pangan di industri jasa boga yang mencakup tahap pembelian bahan pangan, penyimpanan bahan pangan, pengolahan pangan, pengangkutan pangan, dan penyajian pangan.

\section{METODE PENELITIAN}

Penelitian dilaksanakan pada bulan Mei-Juli 2019 di 10 industri jasa boga yang berlokasi di Kota Bogor. Data yang digunakan dalam penelitian ini terdiri atas data primer dan data sekunder. Data primer diperoleh melalui observasi di industri jasa boga, sedangkan data sekunder diperoleh dari Dinas Kesehatan Kota Bogor.

\section{Pengumpulan Data Sekunder}

Data sekunder yang dikumpulkan dari Dinas Kesehatan Kota Bogor ialah data berupa daftar 52 nama dan alamat industri jasa boga yang berlokasi di Kota Bogor yang telah memperoleh Sertifikat Laik Higiene Sanitasi, yang terdiri atas 24 industri jasa boga golongan A2, 24 industri jasa boga golongan $A 3$, dan 4 industri jasa boga golongan $B$. Tidak ada industri jasa boga yang termasuk ke dalam golongan $\mathrm{A} 1$ dan $\mathrm{C}$. Data tersebut selanjutnya digunakan dalam penentuan responden penelitian.

\section{Penentuan Responden}

Penentuan responden penelitian dilakukan dengan teknik purposive sampling. Kriteria industri jasa boga yang digunakan sebagai responden adalah yang memiliki Sertifikat Laik Higiene Sanitasi yang masih berlaku, beroperasi secara rutin, dan bersedia menjadi responden. Berdasarkan kriteria tersebut, dari 52 industri jasa boga yang tercakup dalam daftar yang diberikan Dinas Kesehatan Kota Bogor, terdapat 10 industri jasa boga yang memenuhi kriteria tersebut, yang terdiri atas 2 industri jasa boga golongan A2, 4 industri jasa boga golongan $\mathrm{A} 3$, dan 4 industri jasa boga golongan $\mathrm{B}$.

\section{Pengembangan Checklist}

Checklist terdiri atas dua bagian. Bagian pertama berisi profil responden. Bagian kedua berisi persyaratan untuk melakukan evaluasi pemenuhan prinsip higiene sanitasi dalam pengelolaan pangan. Persyaratan tersebut diambil dari Permenkes 1096/2011 dan dilengkapi good practices dari Kumpulan Modul Kursus Higiene Sanitasi Makanan dan Minuman (Kemenkes 2012).

Setiap persyaratan diberi bobot dengan kisaran 13 berdasarkan tingkat pengaruhnya pada keamanan pangan. Bobot 1 berarti persyaratan tidak berpengaruh langsung, bobot 2 berarti berpotensi menyebabkan bahaya, dan bobot 3 berarti syarat mutlak karena menyebabkan bahaya. Checklist mencakup 51 butir persyaratan dengan total bobot 116. Uji coba checklist dilakukan di 2 industri jasa boga untuk memastikan kelengkapan checklist sebagai alat evaluasi.

\section{Pelaksanaan Observasi}

Observasi pemenuhan prinsip higiene sanitasi dalam pengelolaan pangan dilakukan dengan cara mengamati langsung implementasi persyaratan yang tercantum pada checklist. Persyaratan yang tidak dapat diamati secara langsung dievaluasi melalui wawancara.

\section{Pengolahan Data}

Tahap awal dalam pengolahan data adalah mengkonversi nilai implementasi setiap persyaratan pada checklist yang telah diobservasi, dengan ketentuan 
bahwa nilai baik dikonversi menjadi 2, nilai cukup dikonversi menjadi 1 , dan nilai kurang dikonversi menjadi 0 . Tahap selanjutnya adalah menghitung nilai pemenuhan prinsip higiene sanitasi dalam pengelolaan pangan (nilai akhir) dan per tahapan pengelolaan pangan (nilai per tahapan) dengan rumus berikut.

Nilai pemenuhan prinsip higiene sanitasi

$$
=\frac{\Sigma \text { Bobot }_{\mathrm{i}} \mathrm{X} \text { nilai }_{\mathrm{i}}}{2 \mathrm{x} \text { total bobot }} \times 100 \%
$$

Keterangan:

Bobot $\mathrm{i}=$ Bobot untuk persyaratan butir ke- $\mathrm{i}$

Nilai ${ }_{\mathrm{i}}=$ Nilai implementasi untuk persyaratan butir ke-i

Nilai akhir dan nilai per tahapan tersebut dinyatakan dalam satuan persen (\%) dengan rentang nilai 0 $100 \%$. Berdasarkan nilai yang diperoleh, dilakukan pengkategorian tingkat pemenuhan prinsip higiene sanitasi dengan ketentuan berikut, kategori baik apabila nilai $\geq 80 \%$, kategori cukup apabila nilai 60 $79 \%$, dan kategori kurang apabila nilai $<60 \%$. Pengkategorian tersebut mengacu pada ketentuan Khomsan (2000) dengan sedikit modifikasi pada batas minimal nilai baik.

\section{HASIL DAN PEMBAHASAN}

\section{Porfil Industri Jasa Boga}

Profil industri jasa boga yang menjadi responden penelitian disajikan pada Tabel 1. Pada umumnya, industri jasa boga golongan A2 dan A3 memiliki bentuk usaha berupa perseroan komanditer/ commanditaire vennootschap (CV), sedangkan industri jasa boga golongan B pada umumnya memiliki bentuk usaha berupa perseroan terbatas (PT). Industri jasa boga golongan A2 memiliki tempat usaha yang lebih kecil dibandingkan dengan industri jasa boga golongan $\mathrm{A} 3$ dan B karena dilakukan di rumah tempat tinggal, sedangkan tempat usaha industri jasa boga golongan A3 dan B cenderung besar karena dilakukan di bangunan khusus untuk operasional jasa boga. Industri jasa boga golongan A2 dan A3 melayani kebutuhan masyarakat umum, seperti pada acara pernikahan dengan waktu penyajian tunggal (satu kali penyajian, misalnya satu kali makan siang). Industri jasa boga golongan B melayani kebutuhan masyarakat dalam kondisi khusus, seperti pasien dan dokter rumah sakit dengan waktu penyajian berangkai (penyajian secara terus menerus, meliputi makan pagi, makan siang, makan malam, dan snack).

\section{Tingkat Pemenuhan Prinsip Higiene Sanitasi dalam Pengelolaan Pangan}

Nilai pemenuhan prinsip higiene sanitasi dalam pengelolaan pangan di industri jasa boga golongan A2, A3, dan B disajikan pada Gambar 1. Secara berurutan, nilai yang diperoleh industri jasa boga golongan $A 2$, A3, dan B adalah 60, 74, dan 73\% (kategori cukup).

\section{Tahap Pembelian Bahan Pangan}

Tingkat pemenuhan prinsip higiene sanitasi pada tahap pembelian bahan pangan di industri jasa boga golongan $A 2, A 3$, dan $B$ termasuk dalam kategori baik dengan kisaran nilai $88-91 \%$. Secara ringkas, hasil evaluasi pemenuhan prinsip higiene sanitasi pada tahap pembelian bahan pangan disajikan pada Tabel 2. Tabel 2 menunjukkan bahwa masih terdapat aspek yang belum dipenuhi oleh semua industri jasa boga golongan A2 dan sebagian besar industri jasa boga golongan $A 3$ dan $B$, yaitu pengendalian suhu dingin bahan pangan yang mudah rusak pada saat pengangkutan. Kondisi ini juga ditemukan oleh Sawong et al. (2016) di 3 industri jasa boga golongan A2 dan 7 industri jasa boga golongan A3 di Kota Palangkaraya. Pengendalian suhu dingin penting dilakukan untuk mencegah penurunan mutu pada bahan pangan. Osimani et al. (2011) menyebutkan bahwa mutu bahan pangan yang rendah merupakan salah satu faktor risiko paling umum yang dapat menyebabkan wabah penyakit bawaan pangan. Hasil tinjauan Osimani dan Clementi (2016) mengenai kasus listeriosis yang terjadi di Eropa menunjukkan bahwa salah satu penyebab keberadaan Listeria monocytogenes dalam pangan siap saji adalah mutu bahan pangan yang rendah.

\section{Tahap Penyimpanan Bahan Pangan}

Tingkat pemenuhan prinsip higiene sanitasi pada tahap penyimpanan bahan pangan di industri jasa boga golongan A2 termasuk dalam kategori kurang dengan nilai $55 \%$, di industri jasa boga golongan A3

Tabel 1 Profil industri jasa boga

\begin{tabular}{ccccccc}
\hline $\begin{array}{c}\text { Golongan } \\
\text { jasa boga }\end{array}$ & $\begin{array}{c}\text { No. } \\
\text { responden }\end{array}$ & $\begin{array}{c}\text { Bentuk } \\
\text { usaha }\end{array}$ & $\begin{array}{c}\text { Luas tempat } \\
\text { usaha }\left(\mathrm{m}^{2}\right)\end{array}$ & $\begin{array}{c}\text { Jumlah produksi } \\
\text { (porsi/hari) }\end{array}$ & $\begin{array}{c}\text { Waktu } \\
\text { penyajian }\end{array}$ & $\begin{array}{c}\text { Pengguna } \\
\text { layanan }\end{array}$ \\
\hline \multirow{2}{*}{ A2 } & 1 & CV & 60 & 100 & Tunggal & Umum \\
& 2 & CV & 60 & 300 & Tunggal & Umum \\
\hline & 3 & CV & 60 & 300 & Tunggal & Umum \\
A3 & 4 & CV & 100 & 300 & Tunggal & Umum \\
& 5 & PT & 120 & 1000 & Tunggal & Umum \\
& 6 & CV & 150 & 1000 & Tunggal & Umum \\
\hline & 7 & PT & 100 & 500 & Berangkai & Badan Diklat \\
B & 8 & PT & 100 & 1250 & Berangkai & Rumah Sakit \\
& 9 & PT & 120 & 900 & Berangkai & Rumah Sakit \\
& 10 & CV & 150 & 500 & Berangkai & Pabrik \\
\hline
\end{tabular}




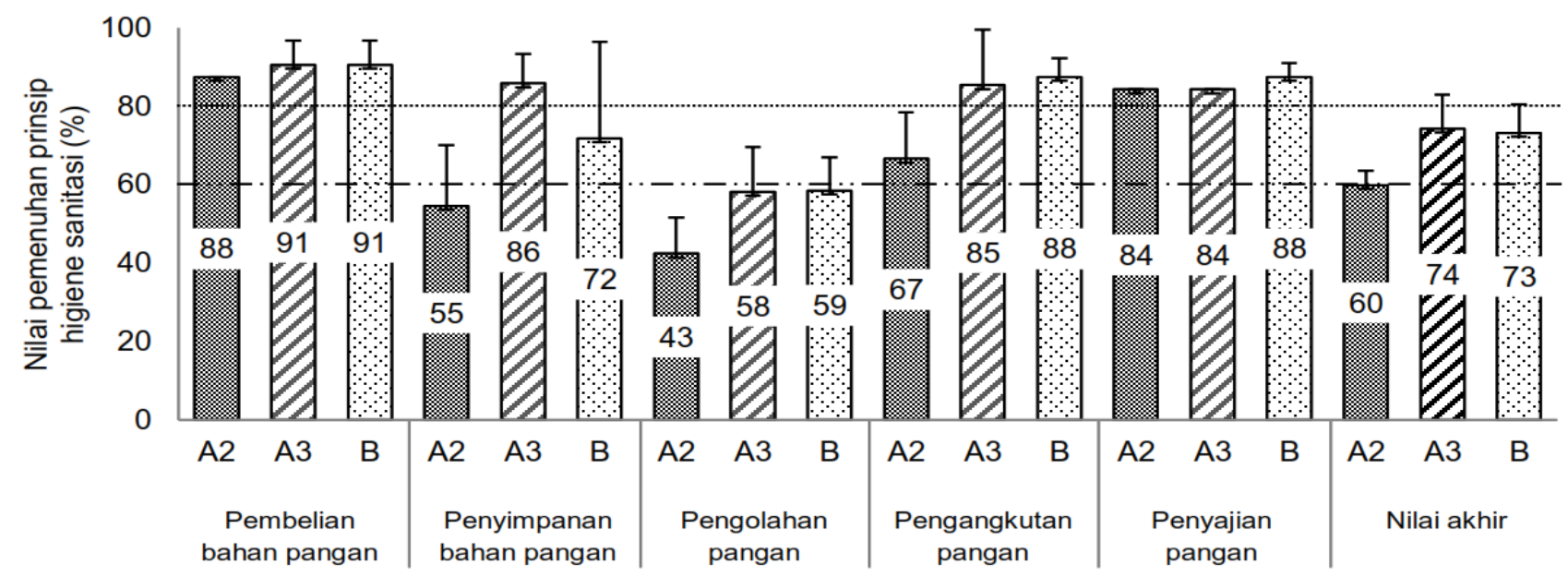

Keterangan: $\quad$.......... Batas minimal kategori baik $\quad$ B... Batas minimal kategori cukup

Gambar 1 Nilai pemenuhan prinsip higiene sanitasi dalam pengelolaan pangan. A2 ( $n=2)$, A3 $(n=4)$, dan B $(n=4)$.

Tabel 2 Ringkasan pemenuhan prinsip higiene sanitasi pada tahap pembelian bahan pangan

\begin{tabular}{|c|c|c|c|c|c|c|c|c|c|c|}
\hline \multirow{2}{*}{ Ringkasan persyaratan (bobot) } & \multicolumn{10}{|c|}{ Implementasi di jasa boga No. } \\
\hline & 1 & 2 & 3 & 4 & 5 & 6 & 7 & 8 & 9 & 10 \\
\hline Membeli bahan pangan dari sumber atau tempat yang baik (3) & 2 & 2 & 2 & 2 & 2 & 2 & 2 & 2 & 2 & 2 \\
\hline Membeli bahan pangan segar dengan mutu yang baik (3) & 2 & 2 & 2 & 2 & 2 & 2 & 2 & 2 & 2 & 2 \\
\hline Membeli BTP yang sesuai dengan regulasi (3) & 2 & 2 & 2 & 2 & 2 & 2 & 2 & 2 & 2 & 2 \\
\hline Membeli bahan pangan olahan pabrikan dengan mutu yang baik (3) & 2 & 2 & 2 & 2 & 2 & 2 & 2 & 2 & 2 & 2 \\
\hline Mencegah kontaminasi pada bahan pangan saat diangkut (2) & 2 & 2 & 2 & 2 & 2 & 2 & 2 & 2 & 2 & 2 \\
\hline Menjaga suhu dingin bahan pangan saat diangkut (2) & 0 & 0 & 0 & 0 & 2 & 0 & 0 & 2 & 0 & 0 \\
\hline
\end{tabular}

Keterangan: 2 = Baik dan $0=$ Kurang.

termasuk dalam kategori baik dengan nilai $86 \%$, dan di industri jasa boga golongan $B$ termasuk dalam kategori cukup dengan nilai $72 \%$. Secara ringkas, hasil evaluasi pemenuhan prinsip higiene sanitasi pada tahap penyimpanan bahan pangan disajikan pada Tabel 3. Tabel 3 menunjukkan bahwa kebersihan tempat penyimpanan bahan pangan di semua industri jasa boga golongan A2 dan sebagian industri jasa boga golongan $\mathrm{A} 3$ dan $\mathrm{B}$ belum terkendali dengan baik. Kondisi tersebut ditemukan pada gudang bahan pangan kering. Hambatan untuk menyimpan stok bahan pangan nabati (sayuran) masih terdapat di salah satu industri jasa boga golongan A2 dan B dikarenakan chiller tidak berfungsi (rusak) dan kapasitas yang terbatas. Pengaturan jarak penyimpanan bahan pangan dengan dinding dan lantai belum dilakukan secara maksimal oleh semua industri jasa boga golongan A2, A3, dan B. Hal ini juga ditemukan oleh Sawong et al. (2016). Keterbatasan jumlah freezer juga menyebabkan tata letak berbagai bahan pangan hewani dengan tingkat cemaran mikrob yang berbedabeda belum dapat diatur secara maksimal.

Semua industri jasa boga golongan A2 dan sebagian industri jasa boga golongan $A 3$ dan $B$ belum melengkapi chiller dan freezer dengan termometer yang berfungsi untuk mengontrol suhu penyimpanan. Pengontrolan suhu penyimpanan diperlukan untuk menjaga mutu bahan pangan yang disimpan dan menghindari penurunan masa simpan bahan pangan akibat pertumbuhan bakteri, seperti yang dilaporkan oleh Lin et al. (2016) bahwa terjadi peningkatan pertumbuhan Pseudomonas fluorescens pada susu yang disimpan pada suhu 4,15 , dan $29^{\circ} \mathrm{C}$.

\section{Tahap Pengolahan Pangan}

Tingkat pemenuhan prinsip higiene sanitasi pada tahap pengolahan pangan di industri jasa boga golongan A2, A3, dan B termasuk dalam kategori kurang dengan kisaran nilai $43-59 \%$. Gambar 1 menunjukkan bahwa tahap pengolahan pangan memiliki nilai pemenuhan prinsip higene sanitasi yang paling rendah dibandingkan dengan tahapan lainnya. Secara ringkas, hasil evaluasi pemenuhan prinsip higiene sanitasi pada tahap pengolahan pangan disajikan pada Tabel 4. Tabel 4 menunjukkan bahwa kebersihan area dapur di semua golongan industri jasa boga belum terkendali. Kondisi tersebut juga ditandai dengan lalat dan hewan peliharaan yang masuk ke area dapur. Seperti yang diketahui bahwa lalat berperan sebagai vektor yang dapat mentransmisi mikrob patogen, seperti Escherichia coli dan Staphylococcus aureus, ke dalam pangan dan risiko tersebut akan semakin meningkat apabila ada hewan peliharaan yang masuk ke area dapur (Barreiro et al. 2013).

Pencucian sayuran yang akan dimakan segar dengan bahan desinfektan yang direkomendasikan belum dilakukan oleh semua golongan industri jasa boga. Pencucian bahan pangan hanya menggunakan 
Tabel 3 Ringkasan pemenuhan prinsip higiene sanitasi pada tahap penyimpanan bahan pangan

\begin{tabular}{|c|c|c|c|c|c|c|c|c|c|c|}
\hline \multirow{2}{*}{ Ringkasan persyaratan (bobot) } & \multicolumn{10}{|c|}{ Implementasi di jasa boga No. } \\
\hline & 1 & 2 & 3 & 4 & 5 & 6 & 7 & 8 & 9 & 10 \\
\hline Memeriksa kondisi bahan pangan sebelum disimpan (1) & 2 & 2 & 2 & 2 & 2 & 2 & 2 & 2 & 2 & 2 \\
\hline Menggunakan tempat yang bersih dan bebas hama (3) & 0 & 1 & 2 & 2 & 2 & 1 & 2 & 1 & 2 & 1 \\
\hline Menyimpan bahan pangan pada chiller atau freezer (3) & 1 & 2 & 2 & 2 & 2 & 2 & 2 & 2 & 2 & 0 \\
\hline Menyimpan bahan pangan kering di tempat tidak lembab (2) & 2 & 2 & 2 & 2 & 2 & 2 & 2 & 2 & 2 & 1 \\
\hline Memberi jarak antara bahan pangan dengan lantai dan dinding (2) & 0 & 0 & 0 & 1 & 1 & 1 & 0 & 1 & 1 & 0 \\
\hline Mencegah kontaminasi silang saat penyimpanan (3) & 1 & 1 & 2 & 2 & 2 & 2 & 2 & 2 & 2 & 1 \\
\hline Menggunakan prinsip FIFO dan FEFO dalam penyimpanan (1) & 2 & 2 & 2 & 1 & 2 & 2 & 2 & 2 & 2 & 2 \\
\hline Melengkapi chiller dan freezer dengan termometer (1) & 0 & 1 & 0 & 2 & 2 & 0 & 0 & 2 & 2 & 0 \\
\hline
\end{tabular}

Keterangan: 2 = Baik, $1=$ Cukup, dan $0=$ Kurang.

Tabel 4 Ringkasan pemenuhan prinsip higiene sanitasi pada tahap pengolahan pangan

\begin{tabular}{|c|c|c|c|c|c|c|c|c|c|c|}
\hline \multirow{2}{*}{ Ringkasan persyaratan (bobot) } & \multicolumn{10}{|c|}{ Implementasi di jasa boga No. } \\
\hline & 1 & 2 & 3 & 4 & 5 & 6 & 7 & 8 & 9 & 10 \\
\hline Menggunakan dapur yang bersih dan bebas dari hama (3) & 1 & 0 & 2 & 2 & 1 & 0 & 1 & 1 & 2 & 1 \\
\hline Menggunakan bidang kerja yang bersih (2) & 0 & 0 & 0 & 2 & 2 & 0 & 2 & 1 & 2 & 0 \\
\hline Menyortir bahan pangan yang rusak (2) & 2 & 2 & 2 & 2 & 2 & 2 & 2 & 2 & 2 & 2 \\
\hline Mencuci bahan pangan dengan air bersih dan mengalir (2) & 2 & 2 & 2 & 2 & 2 & 2 & 2 & 2 & 2 & 2 \\
\hline Mencuci bahan pangan dengan bahan desinfektan/air panas (3) & 0 & 0 & 0 & 0 & 0 & 0 & 0 & 0 & 0 & 0 \\
\hline Menempatkan pangan yang sudah dicuci dalam wadah bersih (2) & 2 & 2 & 2 & 2 & 2 & 2 & 2 & 2 & 2 & 2 \\
\hline Menyimpan kembali pangan yang belum dimasak dalam chiller (2) & 0 & 0 & 1 & 1 & 2 & 0 & 0 & 1 & 1 & 0 \\
\hline Melunakkan daging beku dengan cara yang aman (3) & 0 & 0 & 0 & 0 & 1 & 0 & 0 & 2 & 0 & 0 \\
\hline Menggunakan peralatan yang higienis untuk mengolah pangan (3) & 1 & 1 & 1 & 1 & 2 & 1 & 1 & 1 & 1 & 1 \\
\hline Menggunakan alat berbeda untuk bahan segar dan matang (2) & 0 & 2 & 2 & 2 & 2 & 2 & 2 & 2 & 2 & 0 \\
\hline Menggunakan peralatan yang aman dan tidak terbuat dari kayu (2) & 1 & 0 & 2 & 2 & 2 & 2 & 1 & 2 & 2 & 1 \\
\hline Menggunakan peralatan yang utuh (1) & 2 & 2 & 2 & 2 & 2 & 2 & 2 & 2 & 2 & 2 \\
\hline Mengolah pangan maksimum 3 jam sebelum waktu penyajian (2) & 2 & 2 & 2 & 2 & 2 & 2 & 2 & 2 & 2 & 1 \\
\hline Mengolah pangan dengan panas dan waktu yang cukup (3) & 2 & 2 & 2 & 2 & 2 & 2 & 2 & 2 & 2 & 2 \\
\hline Memeriksa suhu internal daging yang diolah dengan termometer (1) & 0 & 0 & 0 & 0 & 0 & 0 & 0 & 0 & 0 & 0 \\
\hline Mendahulukan mengolah pangan sesuai urutan (1) & 2 & 2 & 2 & 2 & 2 & 2 & 2 & 2 & 2 & 2 \\
\hline Tidak menjamah pangan langsung dengan tangan (3) & 2 & 0 & 2 & 1 & 1 & 0 & 2 & 2 & 2 & 2 \\
\hline Menggunakan sendok khusus untuk mencicipi pangan (3) & 0 & 0 & 0 & 0 & 2 & 0 & 0 & 1 & 1 & 0 \\
\hline Menggunakan alat pelindung pencegah kontaminasi (2) & 0 & 0 & 0 & 0 & 0 & 1 & 0 & 0 & 0 & 0 \\
\hline Menghindari perilaku buruk selama mengolah pangan (3) & 0 & 0 & 0 & 0 & 0 & 0 & 0 & 0 & 0 & 0 \\
\hline Menempatkan pangan terolah dalam wadah yang higienis (3) & 1 & 1 & 1 & 1 & 2 & 1 & 1 & 1 & 1 & 1 \\
\hline Tidak membiarkan pangan dalam kondisi terbuka (3) & 2 & 0 & 1 & 1 & 2 & 1 & 2 & 1 & 2 & 2 \\
\hline
\end{tabular}

Keterangan: 2 = Baik, $1=$ Cukup, dan $0=$ Kurang.

air kran yang mengalir. Harsojo \& Chairul (2011) menemukan bakteri patogen Staphylococcus pada sayuran mentah, seperti kacang panjang, timun, kubis, dan kemangi. Oleh karena itu, sayuran harus dicuci dengan bahan desinfektan, seperti larutan kalium permanganat dengan konsentrasi $0,02 \%$ selama 2 menit atau larutan kaporit dengan konsentrasi $70 \%$ selama 2 menit atau dicelupkan ke dalam air mendidih (suhu $80-100^{\circ} \mathrm{C}$ ) selama 1-5 detik (Kemenkes 2011).

Tabel 4 juga menunjukkan bahwa hampir semua industri jasa boga belum melakukan pelunakan (thawing) bahan pangan beku (daging) dengan metode yang aman untuk menghindari suhu danger zone sehingga tidak menyebabkan pertumbuhan bakteri patogen, seperti Salmonella Typhimurium, seperti yang dilaporkan oleh Roccato et al. (2015). Walaupun thawing pada suhu ruang merupakan metode yang cepat, proses dapat menyebabkan pertumbuhan mikrob patogen apabila suhunya meningkat dan mencapai suhu danger zone (Akhtar et al. 2013). Hal tersebut sesuai dengan hasil penelitian Manios \& Skandamis (2014) yang menemukan peningkatan jumlah Salmonella spp. dan E. coli O157:H7 sebesar
0,7-0,9 log CFU/g pada daging sapi yang dilunakkan selama semalam pada suhu ruang.

Berdasarkan observasi, talenan berbahan kayu digunakan oleh semua industri jasa boga golongan A2 dan sebagian industri jasa boga golongan $B$. Permenkes 1096/2011 tidak merekomendasikan penggunaan talenan kayu karena susah untuk dibersihkan dan dapat mengakumulasi kotoran sehingga mendukung terjadinya pertumbuhan mikrob. Akan tetapi, perlu dilakukan kajian lebih lanjut karena hasil penelitian Lücke \& Skowyrska (2015) menyimpulkan tidak terdapat perbedaan yang nyata antara jumlah mikrob pada permukaan talenan kayu dan plastik setelah pencucian. Higiene peralatan yang digunakan untuk pengolahan pangan perlu ditingkatkan oleh semua industri jasa boga golongan $\mathrm{A} 2, \mathrm{~A} 3$, dan $\mathrm{B}$. Walaupun secara visual kondisi wadah tampak bersih dari debu dan kotoran lainnya, secara mikrobiologi belum dapat dipastikan higienis. Risiko tersebut akan semakin meningkat jika air yang digunakan dalam pencucian adalah air tanah yang tidak diolah terlebih dahulu (Kovacic et al. 2017). 
Pemeriksaan suhu internal daging yang diolah menggunakan termometer belum dilakukan di semua golongan industri jasa boga karena belum tersedia termometer di industri jasa boga. Secara umum, industri jasa boga mengontrol tingkat kematangan pangan yang diolah dengan cara melakukan pengamatan visual, seperti perubahan warna dan tekstur. Hal tersebut ditemukan juga oleh Elsahat et al. (2019). Pemeriksaan suhu internal daging menggunakan termometer bertujuan untuk memastikan tercapainya suhu internal minimal $70^{\circ} \mathrm{C}$ agar dapat mematikan mikrob patogen (Kemenkes 2012).

Pengendalian kontaminasi dari penjamah pangan belum dilakukan dengan baik di semua golongan industri jasa boga. Beberapa penjamah pangan menyentuh pangan yang sudah diolah langsung dengan tangan tanpa menggunakan alat, seperti sarung tangan, sendok, atau penjepit, seperti yang dilaporkan juga oleh Mukhopadhyay et al. (2012). Hal ini berisiko menyebabkan perpindahan bakteri patogen dari tangan ke pangan yang diolah (Lee et al. 2017). Perilaku lain yang dapat mengontaminasi pangan adalah menggunakan pakaian kerja di luar area kerja sehingga dapat membawa mikrob masuk ke dalam lingkungan kerja, termasuk mikrob patogen yang berasal dari anggota keluarga yang sedang terinfeksi (Tood et al. 2010a). Berdasarkan observasi, hampir semua penjamah pangan tidak mencuci tangan pada saat pergantian kegiatan dan setelah menyentuh bahan pangan mentah, bagian tubuh, sampah, atau permukaan kotor lainnya, padahal mencuci tangan dengan sabun dan air bersih merupakan cara yang efisien untuk menghilangkan mikrob patogen dari tangan dan harus dilakukan setiap selesai melakukan kegiatan yang menyebabkan tangan menjadi kotor (Todd et al. 2010b). Assefa et al. (2015) menekankan bahwa tangan merupakan vektor kontaminasi bakteri patogen pada pangan dan dapat menyebabkan insiden keracunan pangan. Kondisi tersebut perlu diperbaiki dan didukung dengan penyediaan fasilitas cuci tangan yang memadai dan perubahan budaya kerja. Berdasarkan observasi, masih banyak penjamah pangan yang menggunakan perhiasan pada saat mengolah pangan, seperti yang dilaporkan juga oleh Ababio \& Adi (2012). Berbicara pada saat mengolah pangan masih sering dilakukan, sedangkan penjamah pangan dalam keadaan tidak menggunakan masker. Kondisi ini juga ditemukan oleh Fatmawati et al. (2013).
Aspek yang perlu ditingkatkan di semua industri jasa boga adalah higiene wadah yang digunakan untuk menempatkan pangan yang sudah diolah karena tidak didesinfeksi pada saat pencucian wadah. Kain lap yang digunakan untuk membersihkan wadah tidak dapat dipastikan higienis sehingga diidentifikasi sebagai sumber kontaminasi mikrob (Todd et al. 2010a). Ada pula industri jasa boga yang mengalasi wadah dengan kertas koran bekas untuk menyerap minyak dari pangan yang digoreng sehingga berpotensi menyebabkan kontaminasi logam timbal pada pangan, terlebih jika pangan dalam kondisi panas maka jumlah logam timbal yang berpindah semakin tinggi (Suwaidah et al. 2014). Hal lainnya yang perlu diperhatikan adalah tidak membiarkan pangan yang sudah diolah terbuka terlalu lama.

\section{Tahap Pengangkutan Pangan}

Tingkat pemenuhan prinsip higiene sanitasi untuk tahap pengangkutan pangan di industri jasa boga golongan A2 termasuk dalam kategori cukup dengan nilai $67 \%$, sedangkan di industri jasa boga golongan $A 3$ dan $B$ termasuk dalam kategori baik dengan nilai 85 dan $88 \%$. Secara ringkas, hasil evaluasi pemenuhan prinsip higiene sanitasi pada tahap pengangkutan pangan disajikan pada Tabel 5. Tahap pengangkutan pangan dimulai sejak proses pewadahan pangan untuk memudahkan dalam pengangkutan. Salah satu industri jasa boga golongan A2 dan A3 melakukan pewadahan di tempat yang tidak terjaga kebersihannya sehingga berisiko mengontaminasi ulang pangan yang sudah diolah dengan sempurna. Higiene wadah untuk mengangkut pangan juga perlu ditingkatkan dengan cara melakukan tahap desinfeksi pada saat pencucian peralatan. Tempat penyimpanan peralatan yang sudah bersih juga perlu dikendalikan untuk mencegah kontaminasi ulang pada peralatan, salah satunya akibat hama.

\section{Tahap Penyajian Pangan}

Tingkat pemenuhan prinsip higiene sanitasi pada tahap penyajian pangan di industri jasa boga golongan A2, A3, dan B termasuk dalam kategori baik dengan kisaran nilai $84-88 \%$. Secara ringkas, hasil evaluasi pemenuhan prinsip higiene sanitasi pada tahap penyajian pangan disajikan pada Tabel 6 . Tabel 6 menunjukkan bahwa aspek higiene peralatan saji dan peralatan makan perlu ditingkatkan oleh semua

Tabel 5 Ringkasan pemenuhan prinsip higiene sanitasi pada tahap pengangkutan pangan

\begin{tabular}{|c|c|c|c|c|c|c|c|c|c|c|}
\hline \multirow{2}{*}{ Ringkasan persyaratan (bobot) } & \multicolumn{10}{|c|}{ Implementasi di jasa boga No. } \\
\hline & 1 & 2 & 3 & 4 & 5 & 6 & 7 & 8 & 9 & 10 \\
\hline Mengqunakan tempat dan bidang keria yang bersih (3) & 2 & 0 & 2 & 2 & 2 & 0 & 2 & 2 & 2 & 2 \\
\hline Mengqunakan wadah pengangkut yang higienis dan utuh (3) & 1 & 1 & 1 & 1 & 2 & 1 & 1 & 1 & 1 & 1 \\
\hline Memisahkan wadah untuk setiap jenis pangan (3) & 2 & 2 & 2 & 2 & 2 & 2 & 2 & 2 & 2 & 2 \\
\hline Memisahkan pangan yang berkuah antara lauk dan kuahnya (1) & 2 & 2 & 2 & 2 & 2 & 2 & 2 & 2 & 2 & 2 \\
\hline Mencegah terjadinya kondensasi uap pangan dalam wadah (1) & 2 & 2 & 2 & 2 & 2 & 2 & 2 & 2 & $\overline{2}$ & 2 \\
\hline Menggunakan kendaraan khusus dan bersih (3) & $\overline{0}$ & 0 & 2 & 1 & $\overline{2}$ & 1 & 2 & 1 & $\overline{1}$ & $\overline{2}$ \\
\hline Mengangkut pangan dalam kondisi tertutup (2) & 2 & 2 & 2 & 2 & 2 & 2 & 2 & 2 & 2 & 2 \\
\hline Menjaga suhu pangan tetap panas/dingin (2) & 2 & 2 & 2 & 2 & 2 & 2 & 2 & 2 & 2 & 2 \\
\hline
\end{tabular}

Keterangan: 2 = Baik, 1 = Cukup, dan 0 = Kurang. 
Tabel 6 Ringkasan pemenuhan prinsip higiene sanitasi pada tahap penyajian pangan

\begin{tabular}{|c|c|c|c|c|c|c|c|c|c|c|}
\hline \multirow{2}{*}{ Ringkasan persyaratan (bobot) } & \multicolumn{10}{|c|}{ Implementasi di jasa boga No. } \\
\hline & 1 & 2 & 3 & 4 & 5 & 6 & 7 & 8 & 9 & 10 \\
\hline Memisahkan setiap jenis pangan dalam wadah penyajian (3) & 2 & 2 & 2 & 2 & 2 & 2 & 2 & 2 & 2 & 2 \\
\hline Mencampur pangan pada saat menjelang disajikan (1) & 2 & 2 & 2 & 2 & 2 & 2 & 2 & 2 & 2 & 2 \\
\hline Hanya menyajikan bahan yang dapat dimakan (1) & 2 & 2 & 2 & 2 & 2 & 2 & 2 & 2 & 2 & 2 \\
\hline Mempertahankan suhu pangan tetap panas selama disajikan (3) & 2 & 2 & 2 & 2 & 2 & 2 & 2 & 2 & 2 & 2 \\
\hline Menggunakan peratalan yang higienis dan utuh (3) & 1 & 1 & 1 & 1 & 1 & 1 & 1 & 1 & 1 & 1 \\
\hline Mencegah kontaminasi selama menyajikan pangan (3) & 2 & 2 & 2 & 2 & 2 & 2 & 2 & 2 & 2 & 2 \\
\hline Menyediakan bank sampel untuk setiap jenis pangan (1) & 0 & 0 & 0 & 0 & 0 & 0 & 0 & 2 & 2 & 0 \\
\hline
\end{tabular}

Keterangan: 2 = Baik, $1=$ Cukup, dan $0=$ Kurang.

industri jasa boga golongan A2, A3, dan B. Umumnya, industri jasa boga maupun jasa penyewaan alat katering belum melakukan desinfeksi pada saat pencucian peralatan, yang berfungsi untuk mematikan mikrob. Puteri et al. (2017) menyebutkan bahwa desinfeksi peralatan makan dapat dilakukan dengan larutan kaporit dengan konsentrasi 50 ppm dan waktu kontak 2 menit yang dapat menurunkan jumlah mikrob sebesar 99,08\%. Hampir semua industri jasa boga belum menyediakan bank sampel untuk setiap jenis pangan yang disajikan, untuk konfirmasi apabila terdapat kasus keracunan atau keluhan dari pengguna layanan (konsumen) setelah mengonsumsi pangan yang diproduksinya. Berdasarkan observasi, hanya 2 industri jasa boga golongan B yang melayani rumah sakit yang sudah melakukan penyediaan bank sampel tersebut.

\section{KESIMPULAN}

Tingkat pemenuhan prinsip higiene sanitasi dalam pengelolaan pangan di industri jasa boga golongan $A 2$, A3, dan B termasuk ke dalam kategori cukup. Tahap penyimpanan bahan pangan di industri jasa boga golongan $\mathrm{A} 2$ dan tahap pengolahan pangan di industri jasa boga $A 2, A 3$, dan $B$ memiliki tingkat pemenuhan prinsip higiene sanitasi yang masih kurang sehingga perlu lebih ditingkatkan.

\section{UCAPAN TERIMA KASIH}

Ucapan terima kasih disampaikan kepada Dinas Kesehatan Kota Bogor yang telah menyediakan data guna penentuan responden penelitian dan kepada industri jasa boga yang telah berpartisipasi dalam penelitian ini.

\section{DAFTAR PUSTAKA}

Ababio PF, Adi DD. 2012. Evaluating food hygiene awareness and practices of food handlers in the Kumasi Metropolis. Internet Journal of Food Safety. 14: 35-43.
Akhtar S, Khan MI, Faiz F. 2013. Effect of thawing on frozen meat quality: a comprehensive review. Pakistan Journal of Food Sciences. 23(4): 198-211.

Arisanti RR, Indriani C, Wilopo SA. 2018. Kontribusi agen dan faktor penyebab kejadian luar biasa keracunan pangan di Indonesia: kajian sistematis. Berita Kedokteran Masyarakat. 34(3): 99-106. https://doi.org/10.22146/bkm.33852

Assefa T, Tasew H, Wondafrash B, Beker J. 2015. Assessment of bacterial hand contamination and associated factors among food handlers working in the student cafeterias of Jimma University Main Campus, Jimma, South West Ethiopia. Community Medicine and Health Education. 5(2): 1-8. https:// doi.org/10.4172/2161-0711.1000345

Barreiro C, Albano H, Silva J, Teixeira P. 2013. Role of flies as vectors of foodborne pathogens in rural areas. International Scholarly Research Notices Microbiology. 2013: 1-7. https://doi.org/10.1155/ 2013/718780

[BPOM] Badan Pengawas Obat dan Makanan. 2017. Laporan Tahunan 2016. BPOM, Jakarta (ID).

[BPOM] Badan Pengawas Obat dan Makanan. 2018. Laporan Tahunan 2017. BPOM, Jakarta (ID).

[BPOM] Badan Pengawas Obat dan Makanan. 2019. Laporan Tahunan 2018. BPOM, Jakarta (ID).

Budiati T, Suryaningsih W, Umaroh S, Poerwanto B, Bakri A, Kurniawati E. 2018. Antimicrobial activity of essential oil from Indonesian medicinal plants against food-borne pathogens. IOP Conference Series: Earth and Environmental Science. 207(1): 012036. https://doi.org/10.1088/1755-1315/207/ $1 / 012036$

Elsahat S, Woodside JV, Mckinley MC. 2019. Meat thermometer usage amongst European and North American consumers: a scoping review. Food Control. 106(2019): 1-12. https://doi.org/10.1016/ j.foodcont.2019.06.018

Fatmawati S, Ali R, Handarsari E. 2013. Perilaku higiene pengolah makanan berdasarkan pengetahuan tentang higiene mengolah makanan dalam penyelenggaraan makanan di Pusat Pendidikan dan Latihan Olahraga Pelajar Jawa 
Tengah. Jurnal Gizi Universitas Muhammadiyah Semarang. 2(2): 30-38.

Harjanti DW, Ciptaningtyas R, Wahyono F, Setiatin ET. 2018. Isolation and identification of bacterial pathogen from mastitis milk in Central Java Indonesia. IOP Conference Series: Earth and Environmental Science. 102(1): 012076. https:// doi.org/10.1088/1755-1315/102/1/012076

Harsojo, Chairul SM. 2011. Kandungan mikroba patogen, residu insektisida organofosfat dan logam berat dalam sayuran. Ecolab. 5(2): 89-96. https:// doi.org/10.20886/jklh.2011.5.2.89-95

[Kemenkes] Kementerian Kesehatan. 2011. Peraturan Menteri Kesehatan Republik Indonesia Nomor 1096/MENKES/PERVI/2011 tentang Higiene Sanitasi Jasaboga.

[Kemenkes] Kementerian Kesehatan. 2012. Kumpulan Modul Kursus Higiene Sanitasi Makanan dan Minuman. Jakarta (ID). Kemenkes.

Kovacic A, Huljev Z, Susi E. 2017. Ground water as the source of an outbreak of Salmonella Enteritidis. Journal of Epidemiology and Global Health. 7: 181-184. https://doi.org/10.1016/j.jegh.2017.05. 001

Lee HK, Halim HA, Thong KL, Chai LC. 2017. Assessment of food safety knowledge, attitude, selfreported practices, and microbiological hand hygiene of food handlers. International Journal of Environmental Research and Public Health. 14(1): 55. https://doi.org/10.3390/ijerph14010055

Lin H, Shavezipur M, Yousef A, Maleky F. 2016. Prediction of growth of Pseudomonas fluorescens in milk during storage under fluctuating temperature. Journal of Dairy Science. 99(3). https://doi.org/ 10.3168/jds.2015-10179

Lücke F-K, Skowyrska A. 2015. Hygienic aspects of using wooden and plastic cutting boards, assessed in laboratory and small gastronomy units. Journal of Consumer Protection and Food Safety. 10: 317-322. https://doi.org/10.1007/s00003-0150949-5

Manios SG, Skandamis PN. 2014. Effect of frozen storage, different thawing methods and cooking processes on the survival of Salmonella spp. and Escherichia coli O157:H7 in commercially shaped beef patties. Meat Science. 101: 25-32. https:// doi.org/10.1016/j.meatsci.2014.10.031

Mukhopadhyay P, Joardar GK, Bag K, Samanta A, Sain S, Koley S. 2012. Identifying key risk behaviors regarding personal hygiene and food safety practices of food handlers working in eating establishments located within a hospital campus in
Kolkata. Al Ameen Journal of Medical Sciences. 5(1): 21-28.

Osimani A, Aquilanti L, Babini V, Tavoletti S, Clementi F. 2011. An eight-year report on the implementation of HACCP in a university canteen: impact on themicrobiological quality of meals. International Journal of Environmental Health Research. 21(2): 120-132. https://doi.org/10.1080/09603123.2010. 515669

Osimani A, Clementi F. 2016. The occurrence of Listeria monocytogenes in mass catering: an overview in the European Union. International Journal of Hospitality Management. 57: 9-17. https://doi.org/10.1016/j.ijhm.2016.05.005

Puteri SNAA, Rahmawati, Darmiah. 2017. Penggunaan alat pengatur konsentrasi kaporit $\left(\mathrm{Ca}(\mathrm{ClO})_{2}\right)$ dalam meningkatkan efektivitas desinfeksi peralatan makan. Jurnal Kesehatan Lingkungan. 14(2). https://doi.org/10.31964/jkl. v14i2.37

Roccato A, Uyttendaele M, Cibin V, Barrucci F, Cappa V, Zavagnin P, Longo A, Catellani P, Ricci A. 2015. Effects of domestic storage and thawing practices on Salmonella in poultry-based meat preparations. Journal of Food Protection. 78(12): 2117-2125. https://doi.org/10.4315/0362-028X.JFP-15-048

Sawong KSA, Andrias DR, Muniroh L. 2016. Penerapan higiene sanitasi jasa boga pada katering golongan A2 dan golongan A3 di Kota Palangkaraya Provinsi Kalimantan Tengah. Media Gizi Indonesia. 11(1): 1-10. https://doi.org/ 10.20473/mgi.v11i1.1-10

Suwaidah IS, Achyadi NS, Cahyadi W. 2014. Kajian cemaran logam berat timbal dari kemasan kertas bekas ke dalam makanan gorengan. Penelitian Gizi Makanan. 37(2): 145-154.

Todd ECD, Michaels BS, Greig JD, Smith D, Holah J, Bartleson CA. 2010a. Outbreaks where food workers have been implicated in the spread of foodborne disease. Part 7. Barriers to reduce contamination of food by workers. Journal of Food Protection. 73(8): 1552-1565. https://doi.org/10.43 15/0362-028X-73.8.1552

Todd ECD, Michaels BS, Smith D, Greig JD, Bartleson CA. 2010b. Outbreaks where food workers have been implicated in the spread of foodborne disease. Part 9. Washing and drying of hands to reduce microbial contamination. Journal of Food Protection. 73(10): 1937-1955. https://doi.org/ 10.4315/0362-028X-73.10.1937 